\title{
CDISC SDTM Vital Sign Test Code Terminology
}

National Cancer Institute

\section{Source}

National Cancer Institute. CDISC SDTM Vital Sign Test Code Terminology. NCI

Thesaurus. Code C66741.

Terminology codelist used with Vital Sign within the Clinical Data Interchange Standards Consortium Study Data Tabulation Model. 